\title{
N. Hawthorne's The Scarlet Letter The Trial of Religion
}

\author{
Nehal EL-Naggar \\ Associate Professor \\ Ain Shams University
}

\begin{abstract}
The trial of religion is a controversial field of research, where questions pertaining to the re-thinking of rigid pseudo-religious dogmas should be addressed and re-examined to fit the modern age and account suitable to match the real life of man on earth with all its changes and advances. Literatures across cultures and across languages along with different ethnic groups have tackled such question with concern; sometimes blatantly and at others subtly. The trial of religion is not directed at condemning any faith or creed but a criticism of dogmatic beliefs that are never part of any religion, but are man-made to exercise power over, manipulate and control people under the umbrella of the sacredness of religion. Needless to say, this is what our age is witnessing nowadays. Everyday, religion is used to destroy peoples and nations with the pretext that we are executing the word of God. Usually, the issue of societal justice emanates from religion. In literature and in the fine arts the implementation of justice is at many times represented through a trial or scaffold scene. World culture abounds in famous trial scenes that had a great impact on literature and that bear witness to the practice of justice or actually 'injustice'. The most well-known are those of Socrates and Christ. In fiction such topic has been at many times represented also in an actual scaffold scene or through a metaphoric one. For instance, Nathaniel Hawthorne's (1804-1864) The Scarlet Letter (SL) (1850). In it the trial of religion is there for the readers to consider and deliberate. It is an attempt to re-think rigid religious dogmas. Nathaniel Hawthorne's (1804-1864) The Scarlet Letter (1850) is a good illustration of the trial of religion. It is the trial of rigid religious dogmas and beliefs. This study proposes to consider the scaffold scenes in The Scarlet Letter in a way to measure their centrality or importance in the text; how they are presented, dealt with and resolved. It will present the ideas that this kind of trial is unfolding to be a pointer to larger issues that are applicable in our modern times. The cultural context is of ultimate importance as it allows the reader to reach out for more universal issues that are pertinent to all times. The Scarlet Letter studies the story of three sinners and the consequences of their acts, which led them to be tried literally, psychologically and metaphorically. The trial is a direct critique of rigid religious understanding. It is the trial of religion by large. What is needed is a different way to think in order to make a change in society. This will challenge the dominant or the accepted social beliefs that have their roots in religion. It offers and visualizes another way to understand and thus to live. This study provides a different context within which we have to face the proliferation of texts that propagate rigid ideologies.
\end{abstract}

\section{INTRODUCTION}

The trial of religion is a controversial field of research, where questions pertaining to the rethinking of rigid pseudo-religious dogmas should be addressed and re-examined to fit the modern age and account suitable to match the real life of man on earth with all its changes and advances. . The trial of religion is not directed at condemning any faith or creed but a criticism of dogmatic beliefs that are never part of any religion, but are man-made to exercise power over, manipulate and control people under the umbrella of the sacredness of religion. Needless to say, this is what our age is witnessing nowadays. Everyday, religion is used to destroy 
peoples and nations with the pretext that we are executing the word of God. Literatures across cultures and across languages along with different ethnic groups have tackled such question with concern; sometimes blatantly and at others subtly. World culture abounds in famous trial scenes that featured differently, the trial or criticism of those rigid religious beliefs. They had a great impact on literature and bear witness to the practice of justice or actually 'injustice'.

The notion of justice and trial has been presented differently throughout the ages. For instance, Socrates' and Christ's where the trial is not essentially verbatim that is, taking place in a traditional court of law, with a usual judge, public prosecutor, accused, jury and defense. However, it could be an allegorical trial. In literature such topic has been at many times represented in an actual scaffold scene or through a metaphoric one. For example, the metaphoric trial and verdict, in Coleridge's Rime of the Ancient Mariner. Moreover, in Shakespeare's Merchant of Venice, a moralistic sermon upon injustice was preached through the trial scene. It could also be traced in modern literature: Kafka's The Trial (1925), Camus' L'etranger (1940), and T. El-Hakim's The Sultan's Dilemma (1960).

Definitely, undertaking to explore the question regarding the trial of religion, necessitates the need to consider the meaning of justice, which should be the main pre-occupation of humanity since, according to Soyinka it is the main condition of being human (The Man Died). Soyinka was imprisoned without trial by the federal authorities at the outset of the Nigerian Civil War. Moreover, Solzhenitsyn states "Justice is conscience, not a personal conscience but the conscience of the whole humanity. Those who clearly recognize the voice of their own conscience usually recognize the voice of justice" (qtd. in Labedz).

This essay intends to explore the trial of religion in Nathanial Hawthorne's (1804-1864) The Scarlet Letter (SL) (1850). It is Hawthorne's criticism of blind dogmas, beliefs and static readings of texts as exemplified in Puritanism. It is an attempt to re-think rigid religious creeds. The trial of religion is there for the readers to consider and deliberate. This text is considered a literary classic. Nowadays, it is important to look at the strict implementation of any belief with re-consideration.

\section{Justice \& Trial}

"A judge is a law student who marks his own examination papers."

\section{H.L Mencken}

Before undertaking to embark on the issue of the trial of religion, we have to try to understand the meaning of justice. Justice has almost always been a discernible concern of humanity, either as an abstract issue or as a hands-on problem. Although, justice may be regarded as godly or social that is worldly, yet in both cases it has socio-cultural dimension. R. W. Baldwin defines justice as " essentially a quality of the behaviour of one man to another, that is of man in society so that all justice is social justice" (Baldwin 1-2). Hence, the flags of justice should rise above considerations of creed, colour, race, sex and religion. Justice should be representative of moral goodness and impartiality and it should be met for all, as it is the essential right of all human beings. As mentioned earlier, the trials of Socrates and Christ are well-known instances that demonstrate the practice of justice in world culture. They are benchmarks in the history of humanity, leaving their influence on world literature. It has been more than two thousand years since Socrates and Plato set off searching for a definition. However, much of the answer is still in dispute. In the Bible, the notion of justice is mentioned around twenty five times. For instance, "When justice is done, it brings joy to the righteous but terror to evildoers" (Proverbs 21:15) and "For I, the Lord, love justice" (Isaiah 61:8) and also "Learn to do right; seek justice" (Isaiah 1:17). According to Baldwin justice is, "giving each his 
due" (15) because it is "closest to righteousness" (Qur'an 5:8), and "when you speak, be just" (Qur'an 6:152) and "if you judge, judge between them with justice"(Qur'an 5:42). The core of the notion is acknowledging each individual as an independent moral individual with rights as a person equal to those of any other person; equally free and responsible for his own life, work and affairs. Thus, there is an assertion on equality of consideration, of liberty, of political rights and treatment. Man is not only a passive receiver but actively responsible for his own actions. However, his due is not only his equal share of nature's provision but also, "all the penalties he may suffer for the injuries he may cause to the 'other' "(Baldwin 25).

Typically, in the arts the question of justice is often represented in a trial, whether it is a scaffold or a court of law or a metaphorical scene in the minds of the viewer or the reader. Man has always been judged for different crimes and accusations. It could be an offence against God, human nature, Nature, or man-made law. Religion and philosophy and the different creeds and faiths were the first to deal, thoroughly with the question of justice. Each of the former delivered its ethical understanding of justice. The question of justice is a historical one, has been there since creation. In ancient Egypt, in Hinduism, Buddhism and in Greek and Roman civilisations the question of justice was always there as long as there was a living human society. Furthermore, in Judaism, Christianity and Islam, this same question was also tackled in detail as an essential precept of any social structure. One of the oldest texts in which a trial is depicted is Plato's Apology, where a demonstration of the trial of ideas and freethinking is portrayed in which Socrates is ultimately censured. The trial of Socrates may bear diverse readings and inferences. It is perceived as the trial of a philosopher who is charged of being "a doer of evil, who corrupts the youth and who does not believe in the gods of the state, but has other divinities of his own" (Plato 10). Furthermore, Christ's trial is meticulously portrayed and deliberated in the four Gospels. Christ was deceitfully charged of imprecation. Even though, Christ's trial may have redemption and salvation, rather than justice as its main concern, however, it is established as an important archetype of unfair conviction that is well known and need no further explanation in this context.

The classic trials, quoted above, exemplify not so much justice, as injustice. It is for the reader to gather how the understanding of moral norms has been distorted. Hence, the tragic irony that is always there in trials seeking justice. This essay will tackle this phenomenon. The trial, as such could be considered as a kind of dramatic confrontation between different groups with different interests and intentions. The characters performing the trial are similar to the dramatic characters where each is presenting his role on the stage of life. However, the stage here is a legal one, that is, the court of law versus religious beliefs and dogmas. Puritanism, in its most rigid forms is the backdrop against which Hawthorne tells his story, which appears to be a simple story of sin and redemption.

\section{Puritanism Re-thought}

"Puritanism. The haunting fear that someone somewhere may be happy."

\section{H.L.Mencken}

Primarily, the Puritans consider "a true believer is a true confessor; he should reveal to God and to the world what he really is" (Edwards 314). Puritanism is all about morals and religion. Originally, Puritanism was a movement that originated in England in the 17th century, reaching power by the end of the English Civil War in 1649 with the defeat and the execution of Charles I, and to be ruled by the Puritan leader Oliver Cromwell who was overthrown in 1660 by Charles II restoring the throne of England. During their rule English theatres were closed, 
being the source of amoral behaviour. As for American Puritanism, it had a strong influence on the thought and thus the behaviour of people, which in turn affected their social everyday life. According to Henry Bowden, "many Puritans emigrated to the New World, where they sought to found a holy commonwealth in New England." And while they believed "in the absolute sovereignty of God, the total depravity of man, and the complete dependence of human beings on divine grace for salvation, they stressed the importance of personal religious experience"(What is Puritanism?). Hawthorne sees the Puritan society with a critical eye, where overt and subtle criticism of the Puritans' practices is there in the text. Moreover, a puritan should follow an inflexible code of behaviour with deep-engrained doctrinal correctness that did not accept any human weakness as he "became identified as one who followed a strict and closely regulated habit of life. The Puritan was a spiritual athlete, characterized by an intense zeal for reform, a zeal to order everything - personal life, family life, worship, church, business affairs, political views, even recreation in the light of God's demand upon him. [...]Moreover! the practice of religion is the business of his life" (Edwards 315).

Clearly, this was not, as will be seen later, the case with Dimmesdale who should have felt "the miracle of grace himself and produced it in others" (Edwards 319). By the end of the 17thcentury England, the Puritan preachers, who had been maintaining upon the necessity for the word of God to be freely preached for three generations, had nurtured a climate of opinion among many of their followers that was antagonistic to any restriction upon the freedom to preach. On the other hand, in the New England colonies, in America, Puritanism was generally understood to mean 'Congregationalism'. These Puritans succeeded to establish Massachusetts Bay colony, which was believed to be the wealthiest, and the most educated in the history of European colonization. These colonists were chosen people, that is "sifted grain" (Edwards 321) with strong clerical guidance. Their plan was to create in the American wilderness a "new Zion" (Edwards 321) that would become "a city set on a hill" (Edwards 323) and face by the power of its example the desired reformation in England. Church membership "was restricted to the regenerate and their children who should own the covenant and only church members enjoyed political rights. Religious uniformity was enforced, and dissenters were informed that they had the right to stay away or to cross the river and to take up land of their own beyond the boundary of Massachusetts. The restrictions were difficult to maintain; there were demands that the franchise be broadened and religious dissent kept appearing" (Edwards 323).

On the other hand, the second generation saw a dwindling of enthusiasm. The clergy understood "recurrent misfortunes as signs of God's wrath with growing laxity, but the adoption of the 'halfway covenant'(1691) was evidence of clerical inability to halt the trend"(Howard 21). Clearly, the character of the New Englanders, was deeply influenced by the Puritan tradition and with the great immigration westward it became a major factor in the shaping of the American spirit. According to Lord Macaulay, "The Puritan hated bear-baiting, not because it gave pain to the bear, but because it gave pleasure to the spectators"(qtd. in Thesaurus). It "is the haunting fear that someone, somewhere may be happy" (qtd. in Thesaurus). Definitely, the most noticeable influences of Puritanism was "the sturdiness of character it produced. The puritan mind was one of the toughest the world has ever had to deal with. It is unconceivable to conceive of a disillusioned Puritan: (Dimmesdale) no matter what misfortune befell him, no matter how often or how tragically his fellowmen failed him, he would have expected no better (Howard 23)."

Those strict Puritans were aware that the way to God and the life of faith was a laborious struggle, and that "sin is a stubborn fact of human existence and that affliction is frequently the 
lot of the saints, but they were nerved by a great elevation to God and by a great confidence in God's overruling Providence"(Howard 27). Inspite of their rigid and strict convictions, the Puritans became the architects who shaped the beliefs of religious freedom. This was partly the result of the fact that the religious diversity they generated bred of necessity a spirit of toleration: "who was to decide who might preach, when God might speak through the humblest of the brethren?"(Howard 51). Hence, Hawthorne, is critiquing the strict Puritan doctrine by way of presenting the scaffold scenes which are a demonstration of this creed or thought. Essentially, it is a trial of those religious dogmatic beliefs that negatively affect the lives of people in any age and in any culture.

\section{The Trial of Religion: A Theatrical Portrayal}

Hawthorne's The Scarlet Letter is a novel that demonstrates the trial of religion as the main action that runs through the whole text. He is using the scaffold scenes as s psychological tool to probe through guilty consciences. However, to get a full understanding of the 'trial' in this novel, we have to examine it closely in its cultural context. The cultural context here is Puritanism. It is a harsh criticism on rigid religious thought which is intolerant to difference. It presents different kinds of trials which all fall into one square by the end of the text: whether actual or virtual the text condemns rigid ideologies. Definitely, the scaffold scenes in this text are open to multiple interpretations and understandings. The Scarlet Letter is not only the story of three sinners who fall into adultery, which led them to be tried either literally or mentally, emotionally and figuratively; with religion as the backdrop in all cases. According to the Merriam-Webster Collegiate Dictionary, adultery is defined as "voluntary sexual intercourse between a married man and someone other than his wife or between a married woman and someone other than her husband." The seventh Commandment of the Ten Commandments pronounce "Thou shalt not commit adultery (Exodus 20:14). Although Hawthorne's text tells the story of an adultress, Hester Prynne with Reverend Dimmesdale and how she is publicly condemned, yet this act entails more than this. Hester Prynne is the heroine of N.Hawthorne's novel. She is accused of adultery. The novel begins with a scene on the scaffold, in the market place of Boston, where the heroine stands in shame closely carrying her baby girl as if to hide the letter "A" on her gown. The red letter "A" that the heroine is forced to wear on her bosom is a symbol of her adultery. Also being the first letter of the alphabet it may stand for the original sin of Adam, in which Puritans believed all men shared. According to Puritans, man is immersed in sin ever since Adam and Eve fell from innocence. That is, man is by nature, sinful. Children in seventeenth century Boston had studied their alphabet from a book that printed a little verse for each letter. The first letter was illustrated by this verse:

In Adam's fall

We sinned all. (Eisinger 101)

This woman whose husband is thought to be lost at sea, has given birth to a child begotten by another man, and she stands in shame unveiling her dishonour infront of the whole society. The leading clerics of the community, along with the guilty lover, Reverend Arthur Dimmesdale, are persistent in their demand that she unravels the name of her child's father, but she refuses. He is a man of religion who should be an angelic figure from the Puritans' point of view. This is considered situational irony. What is more is that on this day of her disgrace, her husband appears. When he sees his wife on the scaffold, he decides to hide his personality and to search for the child's true father. He feigns the name of Roger Chillingworth, and he makes his wife promise to keep his secret. The development in the action of this dramatic representation begins from the opening scenes. From thence, the novel moves inevitably to its 
tragic conclusion. Hawthorne focuses first on Hester's punishment, her suffering, and her psychological fortitude during the next seven years, and then he depicts Chillingworth's resolute pursuit for the closely protected secret. Chillingworth by instinct or black art has been attracted to the guilty Dimmesdale, and in the semblance of a physician and a friend he waits for the final proof. Hawthorne shows us the guilty man's suffering from Chillingworth's point of view, and then we see the priest's full anguish from inside his own mind as he strives ineffectively to make a public confession. Secrecy accentuates the feeling of guilt. Hester decides to protect Dimmesdale, her former lover, after she witnesses his suffering. She asks him to escape with her and her child to another country. But her lover's instinct towards selfdestruction and his over-whelming need to confess make this hope impossible. On the day of planned departure he delivers his last great sermon and then ascends the scaffold. Dimmesdale confesses his guilt before the whole community, asks for Hester's forgiveness, holds his daughter, and dies. Chillingworth, who has abandoned his name in search for retaliation, has no life left. Hester leaves the community but returns for atonement after her daughter grows up.

In The Scarlet Letter there are three scaffold scenes. Each one leads to the other. The first and main trial scene leads to the second and then to the third. This is the expected and subsequent result. They all form one organic whole. The main trial in this novel is presented in chapter two 'The Market Place' and in chapter three The 'Recognition'. However, before introducing the first trial scene, it is important to note that Hawthorne's people were "a people amongst whom religion and law were almost identical, and in whose character both were so thoroughly interfused, that the mildest and severest acts of public discipline were alike made venerable and awful"(SL 91). Hawthorne's mentioning that law and religion are identical is of utmost importance in the unraveling of his critique. As previously stated, Puritans believe that God's will has an important role in the lives of people.

The first scaffold scene takes place in The Market Place. It opens with the women gossiping as they wait. What is most remarkable about their collective character is their rough physiques and intrepid speech. Many are dissatisfied with the lightness of Hester's sentence. For her adultery she is to wear a scarlet letter on the bodice of her dress. She is not to be put to death or branded as stated in Scripture or the Puritan statute book. One of them says that "The magistrates are God-fearing gentlemen, but merciful overmuch, ... At the very least, they should have put the brand of a hot iron on Hester Prynne's forehead" (SL 93). Obviously, these women or 'goodwives' act as "self-constituted judges" (SL 94) who believe themselves to be "churchmembers in good repute"( SL 93). Religion is the way to have a good reputation. Definitely, this understanding of what constitutes a good reputation is questionable. Now, Hester Prynne, the accused, comes out of the prison door. First emerges the grim and grisly town-beadle "This personage prefigured and represented in his aspect the whole dismal severity of the Puritanic code of law, which it was his business to administer in its final and closest application to the offender" (SL 94). Evidently, Hawthorne is describing the Puritan code of law in negative terms in an attempt to condemn this harsh practice that leaves no space for compassion or mercy, which are basic tenets of Christianity. Actually, in the Bible there are twenty-one verses speaking about compassion: "Yet the Lord longs to be gracious to you; therefore he will rise up to show you compassion. For the Lord is a God of justice" (Isaiah 30:18). Justice supplements compassion. Still further, "Have mercy on me, O God, according to your unfailing love; according to your great compassion blot out my transgressions"(Psalm 51:1). Then Hester's exit from the prison silences everyone. It is noticeable that she is different from the other women in more ways than the nature of the crime suggests. She is tall and ladylike and even her clothing is different and shows the recklessness of her nature "On the breast of her gown, in fine red cloth, surrounded with and elaborate embroidery and fantastic flourishes of gold- 
thread, appeared the letter A"(SL 95). As overconfident as her appearance is, Hester is petrified by the grimness of the crowd as she moves towards the humiliating scaffold on which she must stand as part of her punishment "In fact, this scaffold constituted a portion of a penal machine, ... for two or three generations "(SL 99). Hester's only escape from the heavy gaze of the mob is to remember affectionate times. Fleetingly, she dreams of her native village in England, the faces of her now-dead parents and her own face as a younger and happier girl. The present forces itself in again, and she hugs the child so fiercely that it cries out. Only the infant and the shame are real. For Puritans, the sinner has to confess in order to let go of some of the burden of the sin. This scene, as a dramatic presentation, is gradually delineating its major characters. The Reverend Master Dimmesdale stands silent and trembling in the crowd. What we hear form the gossiping women is that he "her godly pastor, takes it very grievously to heart that such a scandal should have come upon his congregation" (SL 93). However, we will soon know how much irony that statement embraces.

Chillingworth, the other major persona is first introduced to us through Hester's drifting thoughts as the image of a 'misshapen scholar'. His actual appearance takes place in the following chapter 'The Recognition'. The staging of characters in this drama-like scene is yet to come. While, Chillingworth makes his appearance on the edge of the crowd facing the scaffold, he is notably described as a man who was wearing strange clothes. This is the misshapen and scholarly-looking man Hester has been thinking about. Just as she recognizes him and seems about to show her reaction to the crowd, he calmly raises his finger and lays it to his lips. And then with what appears to be great self-control he begins asking a man in the crowd the background of the perpetrator and her crime. When Chillingworth knows Hester's crime and sentence, he comments by saying that it is

"A wise -sentence! ... Thus she will be a living sermon against sin, until the ignominious letter be engraved upon her tombstone. It irks me, nevertheless, that the partner of her iniquity should not, at least, stand on the scaffold by her side. But he will be known! - he will be known! - he will be known!" (SL109)

This stranger or Chillingworth hears that Hester refuses to name her lover and that is because of her youth and the possibility her husband maybe dead she will be spared the death sentence, he gives a comment that carries the severity of an oath. While the stranger moves through the crowd, Hester's public inquisition starts. It commences with Reverend John Wilson's pleas -for Hester to confess. Then he turns to Master Dimmesdale, and asks that he continue the exhortation. He tells Dimmesdale ironically "the responsibility of this woman's soul lies greatly with you. It behooves you, therefore, to exhort her repentance, and to confession, as a proof and consequence thereof" (SL 114). In the meantime, Dimmesdale is staged in the trial as a young Clergyman

whose eloquence and religious fervour had already given the earnest of high eminence in his profession .... [Moreover], there was an air about this young minister, - an apprehensive, a startled, a half-frightened look, as of a being who felt himself quite astray and at a loss in the pathway of human existence, and could only be at ease in some seclusion of his own. (SL 114)

Once more, Mr. Wilson makes Dimmesdale feel that it is the latter's responsibility that Hester should confess: "Speak out to the woman, my brother, ..." (SL 115). Mr. Wilson's words serve as a dramatic irony in a play. These words bear more than one meaning. For the onlookers of this trial Dimmesdale acts as the guardian of Hester. Thus, he is responsible for her acts and 
consequently for her confession. On the other hand, we, as readers are aware that he is as responsible for her sin as she is. Or as Mr. Wilson says he is in charge of her and her confession. Reverend Mr. Dimmesdale begins his plea:

"Hester Prynne,"...." thou hearest what this good man says, and seest the accountability under which I labor. I thou feelest it to be for thy soul's peace, and that thy earthly punishment will thereby be made more effectual to salvation, I charge thee to speak out the name of thy fellowsinner and fellow- sufferer!" ( SL 115)

Inspite of the fact that the minister's appeals are so authoritative and commanding that the people believe for the moment that Hester will name her seducer, or that the guilty one himself would be compelled to ascend the scaffold, however, the question leads to nothing. Contrary to their expectations she says: " "Never!" .... " It [the name] is too deeply branded. Ye cannot take it off. And would that I might endure his agony, as well as mine!" " (SL 117). Likewise, another voice in the crowd advises her to speak out. Conversely, being resolute she says: "I will not speak!" ... " And my child must seek a heavenly Father; she shall never know an earthly one!"” (SL 117). Still, another clergyman begins a sermon on sin that lasts well over an hour. Time and over again he refers to the scarlet "A", and the embroidery on Hester's dress seems lit with Hell-fire. In the meantime, Hester Prynne "kept her place upon the pedestal of shame,... [And] With the same hard demeanor, she was led back to prison, and vanished from the public gaze within its iron-clamped portal" (SL 118). Definitely, this scene serves partly as a staging of the characters included in this dramatic presentation. The satanic and scholarly-looking stranger is set against the angelic and almost effeminate-looking Dimmesdale. Within this contrast the narrator manages to interlace many verbal ironies. Whatever the stranger says is true enough, but we will soon understand that it is truth jeered with infernal malice. Hester's seducer will be revealed, but not for the moral intentions the stranger's comments imply. Dimmesdale's comments are also morally valid. As he himself says, Hester's persistence shows 'wondrous strength' and kindness in protecting her lover. In his pleading Dimmesdale says that she disregards whatever reputation the man may have, for he (the lover) is as guilty as she. All quite true, and as we discover, all apply, in full force to him, the yet-to-be-discovered partner. Dimmesdale's reactions to his remarks and Hester's quiet refusals are as much as an assessment of his own guilt as they are an indication of his fear of being discovered. The inconsistency of his observations emblematically forecast, guilt and fear, conscience and hypocrisy that will slit his personality in two when he falls prey to the penetrating nature of the stranger. Eventually, this will lead to the second allegorical scaffold scene. Clearly, the first scaffold scene stages and presents all the dramatic personae included in this representation.

The second scaffold scene which takes place in chapter twelve 'The Minister's Vigil' is figurative. It is Mr. Dimmesdale who climbs the scaffold this time: "Walking in the shadow of a dream, ... Mr. Dimmesdale reached the spot where, now so long since, Hester Prynne had lived through her first hours of public ignominy. The same platform or scaffold, black and weather stained ... The minister went up the steps" (SL 231). Dimmesdale standing on the scaffold was like a "vain show of expiation" (SL 233). Furthermore, he "was overcome with a great horror of mind, as if the universe were gazing at a scarlet token on his naked breast, right over his heart" (SL 233). It is a cloudy night in early May, and as he stands there, Dimmesdale, feels that the act is much like his other public confessions and secret atonements. Time and again,

He had been driven hither by the impulse of that Remorse which dogged him everywhere, and whose iron sister and closely linked companion was that Cowardice which invariably drew him back, with her tremendous gripe, just when the other impulse had hurried him to the verge of a disclosure. (SL 232) 
Temporarily, Dimmesdale feels that he will be finally exposed, but the cry is no more than a sob. Only Governor Bellingham, who sleeps lightly, and his sister Mistress Hibbins have heard the noise, but they soon return to bed. Dimmesdale becomes relatively tranquil again, and he notices a lantern light forthcoming in the darkness. It is Reverend Wilson returning from the deathbed of former Governor Winthrop. As Wilson passes, Dimmesdale imagines that he speaks out inviting the old man up there with him. This fantasy is followed by a series of hallucinations. Now Dimmesdale sees the village gradually awake and all hastening to stare at the lonely figure. Carried away by the incongruous horror of this picture, he begins laughing, and it is only the sight of Pearl and Hester returning from the same deathbed that reinstates his sense of reality. He asks them to ascend the scaffold with him. He bids them to "Come up hither, Hester, thou and little Pearl,"... "Ye have both been here before, but I was not with you. Come up hither once again, and we will stand all three together!" "(SL 239). Unlike his former invitation to Wilson, this one is heard, and the three join hands on the stage. Dimmesdale, for the first time since Hester's public trial feels

a tumultuous rush of new life, other life than his own, pouring like a torrent into his heart, and hurrying through all his veins, as if the mother and the child were communicating their vital warmth to his half-torpid system. The three formed an electric chain. (SL 239)

Pearl appears stirred by the gravity of the instance and she asks "Wilt thou stand here with mother and me tomorrow noontide?" (SL 240). Dimmesdale says that he will stand with her and her mother some other day, but not tomorrow. Still, when Pearl repeats her question the minister gives only half an answer:

"At the great judgment day," ... "Then, and there, before the judgment seat, thy mother, and thou, and I must stand together. But the daylight of this word shall not see our meeting!" (SL 240).

Pearl then laughs. But, before Dimmesdale finishes his explanation a meteor lights the sky, and the three stand illumined: Hester with her scarlet letter, Dimmesdale with his hand on his heart, and Pearl as the link between the two adults. Pearl now looks as if touched with witchcraft in the strange light, and she points to Roger Chillingworth standing near the scaffold. Dimmesdale is frightened of the bizarre looks of the man, and he turns to hear what Pearl has to say about him. The child mutters nonsense in his ear and laughs again. She scolds him for his cowardice, and the doctor guides a disturbed minister home. This is the second of three scaffold scenes, and it designates that the action will rush downward now to its unavoidable conclusion: the third and last scaffold scene.

In this symbolic trial scene, Dimmesdale's responses on the scaffold show how near to madness he is. While the three people seem to embody the happy Christian family, their presence on the scaffold is "tainted with Dimmesdale fear" (Mcpherson 157). If anything, the three are "a mockery of family life and of the love which exists between Hester and Pearl because of Dimmesdale"(Mcpherson 160). Chillingworth does not feel this, of course: the company before him with its "supposed unity will only give him more cause for spite as he thinks of the family life he has been denied"(Mcpherson 161). Pearl is only a child and there is no reason to presume that she is conscious of the special implication of this meeting. She has asked for a friend and a "protector who will publicly associate himself with her and her equally outcast mother"(Becker 131). She is denied and she chides Dimmesdale, because "she is too 
young to be satisfied with abstractions about judgment day"(Becker 135). When he turns to hear what she has to say about the doctor, she is only irritating him. Dimmesdale holds the key to his salvation, and action, not abstraction, will save him. He cannot understand Pearl's mumbling because he cannot understand himself; he has "been denied any special insight into the role of Chillingworth because he has refused to do anything positive to earn that insight"(Becker 140). Moreover, Pearl is the link between Hester and the minister; she is here not an elfin sprite but "truth and honest action, and Dimmesdale does not have the courage to clasp it with both hands" (Waggoner 101).

It is important to notice that in the second scaffold scene - although it is metaphoric - all major characters in this dramatic representation are brought together. This is not their final appearance together as they will be staged again in the third scene. Hence, holding the unity of the three scenes together. Moreover, it is of significance to note that the three scaffold scenes are considered as one complete dramatic representation with all the baggage of a play. The first scaffold scene is the beginning or introduction; the second is the middle or climax, which in return will lead to the third scaffold scene which is the conclusion. Actually, each one of these scenes is a play in itself -a one-act-play- and the three together comprise one longer, intricate play.

\section{The Scarlet Letter Revealed}

The third scaffold scene is concluding to this dramatic representation. It takes place in chapter twenty-three, 'The Revelation of the Scarlet Letter'. In the previous chapter, The Procession, the whole town gathered heading towards the meetinghouse; where in fulfillment with a custom thus early recognized, and ever since observed, the Reverend Mr. Dimmesdale was to provide an Election Sermon. His trembling voice has reached every corner of the church, and the assembly stood mesmerized as he spoke of the new civilization being cut out of the New England wilderness and the new destiny for these newly gathered people of the Lord. It is evident how Hawthorne is critical of the religious institution. As the congregation reached the open area of the market place, their ecstasy broke into speech. According to their united testimony, never had any man spoken in so wise, so high, and so holy a spirit as he had this day. But through it all there has been an assured deep, sad tinge of anguish, which could not be, construed other than as the natural repentance of one soon to die. This sense of his temporary stay on earth gave the final status, that the preacher was an inspired angel who had shuddered his bright wings over the Salem people and "showered golden truths upon them" (Waggoner 109). He stands at this moment, on the "very pinnacle of his spiritual reputation and his eloquence"(Waggoner 131). Hester still stands beside the scaffold of the pillory. Although this could be regarded as dramatic irony, yet it could also be looked at as a severe criticism of the hypocrisy of rigid religious beliefs. It is revealing of the fact that some men of religion say what they do not perform. This is the core of Hawhtorne's condemnation of Puritanism: the pretense and insincerity that would always result in the misunderstanding of religious directives that should guide man to lead a good ethical life.

Once again the procession of magistrates moves through the crowd that in a highly charged spirit shouts its acclaim for the venerated preacher. As Dimmesdale moves through the crowd, its shouts are reduced into whispers; his temperament is considerably transformed, as if all "the eloquence had drained his life's blood" (Waggoner 133). Reverend Wilson moves forward to stretch his arm, but the young minister waves him back. As Dimmesdale approaches Pearl and Hester, he stops, and before Governor Bellingham can reach him to offer help to the pending festivities, Dimmesdale extends his arms towards the scaffold and calls Pearl and Hester ""Hester"said he, "come hither! Come, my little Pearl!" "(SL 385). Hawthorne observes 
It was a ghastly look with which he regarded them; but there was something at once tender and strangely triumphant in it. The child, with the bird-like motion, which was one of her characteristics, flew to him, and clasped her arms about his knees. Hester Prynne - slowly as if impelled by inevitable fate, and against her strongest will - likewise drew near, but paused before she reached him. ( SL 385)

Yet, Chillingworth is near and blasts through the mass of astounded people saying:

"Madman, hold! What is your purpose? ... Wave back that woman! Cast off this child! All shall be well! Do not blacken your fame, and perish in dishonour! I can yet save you! Would you bring infamy on your sacred profession?" (SL 386)

Dimmesdale shouts back at his tempter saying:

"Ha, tempter! Methinks thou art too late!" ...

"Thy power is not what it was! With God's help

I escape thee now!" (SL 386)

Once again, he "extended his hand to the woman of the scarlet letter," (SL 386) crying loudly:"Hester Prynne," ... "in the name of Him, ... come hither now, and entwine thy strength about me!...Come, Hester, Come! Support me up younder scaffold!" (SL 386). Hawthorne, here, verifies the idea that this is a dramatic representation when he remarks:

The crowd was in a tumult. The men of rank and dignity, ...were so taken by surprise, ...

- unable to receive the explanation which most readily resented itself, - that they remained silent and inactive spectators of the judgment which Providence seemed to work. They beheld the minister, leaning on Hester's shoulder, and supported by her arm around him, approach the scaffold, and ascend its steps; while still the little hand of the sin-born child was clapped in his. Old Roger Chillingworth followed, as one intimately connected with the drama of guilt and sorrow in which they had all been actors, and well entitled, therefore, to be present at its closing scene! (SL 385-387)

Moreover, Chillingworth tells the minister that there is no place on earth that he could have escaped him, "Save on this very scaffold" (SL 387). Dimmesdale goes on in his confession in the shining sunlight:

"For thee and Pearl, be it as God shall order,"

make haste to take my shame upon me!

"People of New England! " ... " ye, that have

loved me! - ye, that have deemed me holy! - behold me here, the one sinner of the world! At last - at last! - I stand upon the spot where, seven years since, I should have stood; here, with this woman."(SL 388-389)

Dimmesdale, in his powerlessness and feebleness of heart, struggled to divulge the rest of his secret:

"It was on him!" ... "God's eye beheld it! The angels were forever pointing at it. The Devil knew it well, and fretted it continually with the touch of his burning fingers!

Stand any here that question God's judgment

on a sinner? Behold a dreadful witness of it!" (SL 389-390) 
By the end, he rips open his clothing as if to display some ugly and concealed wound to the horror-struck crowd. Then down he falls upon the scaffold. As he breaks down, Chillingworth turns to Dimmesdale and shouts that he has fled him. In all this the doctor's appearance has changed also, and he seems to be as pale as his one-time victim. There is not much time, and young Pearl imparts all her childish and tear-filled love to this man in a single kiss. Hester asks if they shall at least be together in the life hereafter, but Dimmesdale still has too much repentance to relieve her even now:

"Hush, Hester, hush!" said he, with tremulous, solemnity. "The law we broke! - the sin here so awfully revealed! - let these alone be in thy thoughts! I fear! It may be that, when we forgot our God, - when we violated our reverence each for the other's soul, - it was thenceforth vain to hope that we could meet hereafter, in an everlasting and pure reunion.

God knows; And He is merciful!

Praised be his name! His will be done! Farewell!" (SL 391-392)

And so dies Dimmesdale reminding her of their sin and the ever-present justice of God. Evidently, the third scaffold brings the action to an end, where all the main dramatic personae are brought together. The different characters need no "verbal amplification to show all of their relationship one to the other" (Bell 61). Here again, like the former scaffold scenes, Hawthorne has created an enlarged image. Obviously, it is a complete depiction of all the suffering in the love triangle. Hawthorne has re-engaged several of the actions or images related earlier, in the other scaffold scenes. Hester stands by as an angel of mercy strengthening the weak and comforting to the dying. The doctor turns over the dying man as a real physician would to dispense the last physical comforts. Dimmesdale for the first time is covered in the full light so often connected to Pearl, and yet his confession is tainted with the "hypocrisy and cowardly masochism" (Bell 67) mentioned earlier. His speech begins with 'I' but ends in the third person. He splits open his clothing to exact as much punishment as possible on himself at this last minute, but it is done in such apparent suffering that part of the crowd at least is not fully aware of his reason or his clarification. Definitely, his last words are a confirmation that he is still committed to a pessimistic view of himself and Hester. He cannot pacify Hester, but simply says, that God's will be done. Dimmesdale can claim only to have redeemed himself from hell-fire by his final "triumphant agony" as he calls it, but he is in no way persuaded that his love for Hester and hers to him is worth anything. The question then arises whether Dimmesdale dies in this way to absolve Hester or to free himself from more anguish here and hereafter? There is no final answer because Hawthorne has kept the workings of Dimmesdale's mind on this last day hidden from the reader or spectator.

What came about in the last scaffold scene, or the conclusion of this dramatic portrayal, distressed even Pearl. Hawthorne stated that she wept in compassion for the first time in her life, and that as she kissed her father, she achieved wholeness as a human being, empowering her now to grow within the joys and sorrows of life. Pearl is no longer considered as the fragile innocent creature of earlier times. Her role as aide-mémoire of pretense is no longer required. This may appear "like so much allegorical magic on Hawthorne's part, that is to say, since the spirit of evil and hypocrisy has been vanquished Pearl's supernatural character is no longer needed as a foil"(Bell 69). However, any huge passionate experience can change the estranged personality of a youngster to a more conventional and social outlook and this is precisely what happened to Pearl here. She has briefly won a father, learned to love someone besides her mother, and "gained an ally from the society which estranged her, and she is the better for this" (Bell 71). On the figurative level a similar transformation had to occur, and it does, "but one is 
not necessarily a supernatural consequence of the other, rather the symbolic change is a literary consequence of a change in Pearl's natural personality and environment"(Pearce 21). Cillingworth's position in all this disorder is never clearer than these final minutes. Hawthorne portrays Chillingworth not as a man, what we see instead is the figure of Satan soaring over a departing soul. Pearl is fully human now and Hester always was, but the physician is a "caricature from some medieval representation of the fallen angel"(Pearce 23-24). Gerard Manley Hopkins wrote something about the essence of man and all natural objects which relates particularly to Chillingworth: "What I do is me, for that I came" (SL 103).

Ultimately, he has become the sum total of his unnatural doings. Thence, the curtains fall and the play ends as represented through the scaffold scenes. These scenes show the eternal conflict between rigid religious beliefs and man's life on earth. Hester trusts that one should wait for "the heavenly justice to strike" (SL 201). The question of justice will always resonate, as it is an incessant issue reminiscent of humanity. Moreover, there will always be an attempt to find an answer. Time and again, Hawthorne is condemning the rigid Puritan convictions that at many times could lead to injustice. Actually, it is a trial of those religious dogmas that negatively disturb the lives of people. They are those kind of dogamatic beliefs that affect the lives of people in any age and in any culture.

\section{CONCLUSION}

Evidently, any form of creed or religion must be understood by way of its relative centrality to man's daily life but not overriding to all aspects of life. This is what Hawthorne has tried to convey in his text, that the imposition of religion in all ways of life would result in hypocrisy or illusion. Clearly, this is because those people who are faithfully capable of making religion their sole goal in life and the source and reason of living are very rare. They are those who can inhibit and curb their natural desires and abstain from getting overpowered by human desires. Human beings are not prophets or saints. This is what happened in the story. The character of the disenchanted and deceitful man of religion becomes a clear proof of the result of adopting dogmatic and unbending religious principles. This clergyman has put on the robe of religion while sinning in the dark. However, this does not imply that all men of religion are hypocrites. It simply means that we are normal human beings with natural desires.

Actually, the trial of religion is a criticism directed to any rigid and strict belief or creed that leads man to develop a double standard way of life. Religion commands man to good and honest behaviour without hurting fellow human beings. The standard of being a virtuous individual is ones actions in daily life. This is an imperative to the way of God. In his criticism of rigid religious beliefs, Hawthorne scrutinized the practice of religion as epitomized in Puritanism, which considers religiosity as the adherence to strict bleak moral, religious practice. Religion fulfills some of the needs of life but it is not the whole of life. Man's life on earth is multi-dimensional; not entirely the performance of religious chores. Real religious beliefs should help man maintain an honest life, not a list of do's and do not's. Religion is not blind but it is the way to see, to understand to think scientifically for the benefit of humanity. In his development, man had realized many achievements that led to many scientific discoveries and advancements that served humanity and had nothing to do with religion. Thence, religion is part of man's life that guides him to uphold decent human relationships. Thus, regarding religion as the one and only source for comprehending man's worldly needs would be an incomplete and an inadequate understanding that would lead to damaging effects, similar to what our age is suffering from at the present. 
Hence, it is important to look at the strict implementation of any belief with re-consideration. The Scarlet Letter is considered a progressive text. Hawthorne tried to embody a pure and idealistic society where adultery and betrayal appear to be the theme whereas much more underlie this account. It is not just a story about sin and redemption. It is the trial of religion by large. What is needed is a different way to think in order to make a change in society. This will challenge the dominant or the accepted social beliefs. It offers and visualizes another way to understand and thus to live. This study is a pointer to re-consider the proliferation of any text that propagates rigid ideologies. Finally, religion is not entirely life and it cannot be - religion constitutes the guidelines, which are part of life and should remain so 


\section{BIBLIOGRAPHY}

Baldwin, R. (1966). Social Justice. Oxford: Pergamon Press.

Becher, J. (1971). Hawthorne's Historical Allegory. Port Washington: Kennikat Press.

Bell, M. (1971). Hawthorne and the Historical Romance of New England. Princeton: Princeton University Press.

Bowden, H. (n.d.). What is Puritanism? The History, and Differences, of English and American Puritanism. Retrieved April 08, 2017, from Scholastic.com: https://www.scholastic.com/teachers/articles/teachingcontent/what-puritanism.html

Collin Thesaurus of the English Language (Third edition ed.). (2008). Glasgow: HarperCollins Publisher.

Edwards, I. (1865). The Works. London University Press.

Eisinger, G. (1901). The Puritan Heritage. Cambridge: Cambridge University Press.

Hawthorne, N. (1940). The Scarlet Letter. Chicago: University of Chicago Press.

History.com Staff. (2009). Puritanism. Retrieved April 08, 2017, from History.com: www.history.com/topics/puritanism

Hopkins, G. (1983). The Complete Poems. Cambridge: Cambridge University Press.

Howard, L. (1905). Puritanism. Oxford: Oxford University Press.

Labedz, L. (Ed.). (1971). Solzhenitsyn: a Documentary Record (1st edition ed.). New York: Harper \& Row.

Mcpherson, H. (1979). Hawthorne as Myth-Maker: A Study in Imagination. Louisiana University Press.

Mencken, H. (n.d.). H. L. Mencken Quotes. Retrieved May 30, 2017, from Brainy Quote:

https://www.brainyquote.com/quotes/authors/h/h_l_mencken.html

Merriam-Webster Collegiate Dictionary (11th edition ed.). (2003). Springfield, Massachusetts: Merriam Webster Inc. .

Pearce, R. (Ed.). (1964). Hawthorne Centenary Essays. Ohio State University Press.

Plato. (1927). Apology. (B. Jowett, Trans.) New York: Liveright Publishing Corp.

Soyinka, W. (1972). The Man Died: Prison Notes of Wole Soyinka (1st edition ed.). London: Rex Collings.

The Glorious Qur'an: Text and Translation. (1996). (A. Zidan, \& D. Zidan, Trans.) Cairo, Egypt: Islamic Home Publishing and Distribution.

The New English Bible: New Testament. (1961). New York: Oxford University Press.

Waggoner, H. (1930). Hawthorne, A Critical Study. The Belkanays Press of Harvard University Press. 